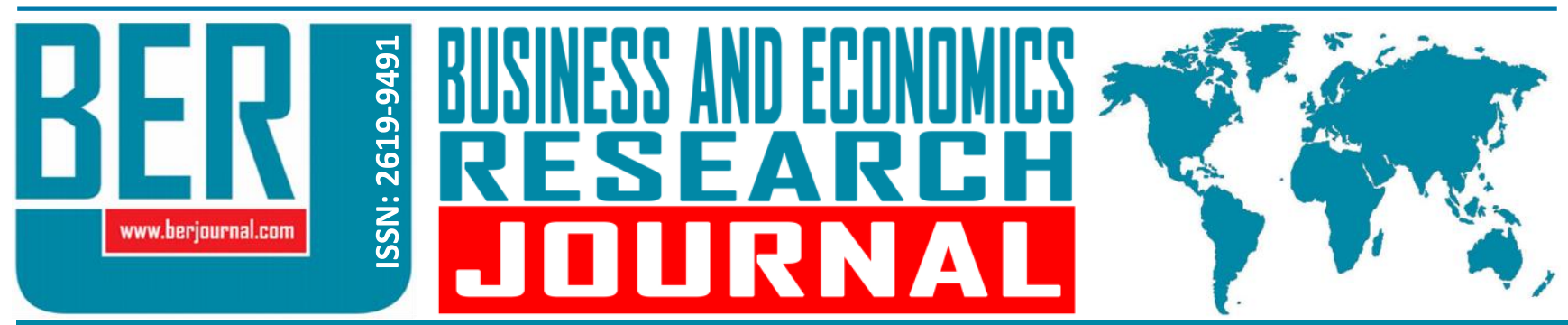

Business and Economics Research Journal Vol. 9, No. 3, 2018, pp. 463-479 doi: 10.20409/berj.2018.117

\title{
Foreign Technology Absorption in Sub-Saharan Africa: A Long-Term Analysis of the Nature and Stability of Relationships
}

\section{Katarzyna Świerczyńska ${ }^{\mathrm{a}}$, Agata Kliber ${ }^{\mathrm{b}}$}

Abstract: The goal of this paper is to investigate the relationships between the process of technology absorption, official development aid (ODA), foreign direct investment (FDI), and import in Sub-Saharan Africa. We investigate long-run relationships between the process of technology absorption in the region. The investigation is based on such variables as ODA, FDI as well as import from developing and developed economies to estimate co-integration relationships and error-correction models. The results obtained indicate that aid and import from the South are more likely to cause the absorption of technology than other directions of flow.

\author{
Keywords: Sub-Saharan \\ Africa, Foreign Technology \\ Absorption, Official \\ Development Aid, Foreign \\ Direct Investment \\ JEL: 011, 055, F35 \\ Received : 11 January 2018 \\ Revised : 27 February 2018 \\ Accepted : 30 April 2018 \\ Type : Research
}

\section{Introduction}

The relationships between technology, economic growth, and development are recognised by many scholars, starting with the Solow model (1956). The theories of exogenous and endogenous growth recognise advancement in technology as beneficial to economic development. Technological changes and industrial upgrading are deemed crucial for economic growth not only according to the theory of convergence, but also to new structural economics (Young et al., 2008; Lin, 2011). The less developed economies, due to the enormous unused potential, are capable of boosting their technological strengths by means of a relatively small capital input (Rapacki \& Prochniak, 2009). Modern production processes, tools, higher quality goods and services, novel methods and solutions are considered to be the components of technology. They all lead to the more efficient use of the existing resources (Kaplan, 1999, Yelpaala et al., 2012; Comin \& Mestieri, 2013), especially in the case of laggard economies. Making the economy more open to international knowledge is expected to increase the technological capacity of local industry regardless of the nature of the

a PhD., Poznan University of Economics and Business, Faculty of Economics, Poznan, Poland, katarzyna.andrzejczak@ue.poznan.p (ORCID ID: 0000-0002-0439-783X)

b PhD., Poznan University of Economics and Business, Faculty of Economics, Poznan, agata.kliber@ue.poznan.pl (ORCID ID: 00000003-1996-5550)

Acknowledgements: The research is supported by the Polish Ministry of Science and Higher Education through the Project Sonata no. DEC-2013/09/D/HS4/01849 “Mechanisms of technology application in sub-Saharan Africa". The authors would like to thank the participants of the International Conference on Emerging Markets Economies - Euroconference 2016 (29.06-

01.07.2016, Porto, Portugal) for the discussion and comments on the early version of this paper. 
inflows (technology transfers sensu stricto or indirect transfers in the scope of imports, projects or programmes; Pack \& Paxson, 1999).

However, over the last 50 years, there was very little economic convergence between rich and poor countries, despite the many efforts that have been made (Lin, 2011). According to the conditional convergence theory, the differences in structural characteristics of economies imply that each economy tends to its own long-run equilibrium, which is unique and determined by the characteristics of that economy (Farahmand et al., 2014). Hence, the concepts and panaceas implemented in one region do not necessarily work in other regions. In the region of Sub-Saharan Africa (SSA), the level and pace of economic growth not only differ from the level and pace exhibited on other continents, but they also vary within the region itself. Each country in the region can converge or diverge at its own pace, despite being spatially interdependent. Poorer countries may not necessarily boast a faster pace of convergence (Farahmand, et al., 2014). This may be partially explained by the weakness of their market and state institutions, governance issues, and the quality of infrastructure (Oluwatobi, 2015). Moreover, the region is still very mindful of the harrowing experience related the implementation of the structural adjustment policy (Husain \& Ishrat, 1994).

In this paper, we assume that despite the differences and past experiences, research and development can be the engine of growth (Silverberg \& Verspagen, 1995) in the catching-up process for the Sub-Saharan region. A real structural change in the economy and moving labour from low to high productivity sectors may contribute positively to Africa's overall growth of productivity, as it did happen after 2000 (McMillan et al., 2014). We treat Sub-Saharan Africa (with the exception of South Africa) collectively: despite the differences among the countries in the region, their technological and institutional progress, as well as the infrastructure factors, make them much more different from the rest of the world rather make any of the countries within that group distinctive from its other members. We acknowledge that the effectiveness of the technology transfer processes depends on a number of characteristics of a given country. The assumption is that once technology is absorbed in the economy, it can stimulate its growth. The objective is, therefore, to investigate which transfer channels are the most effective.

Several potential channels of the technology transfer to Sub-Saharan African region are named. They differ in terms of their character and source. From the macro perspective, technology can be brought in from the outside of the country in the form of for-profit (foreign direct investments, imports) and non-profit interventions (public and private flows of aid) ${ }^{1}$. From the micro perspective, foreign technology is transferred at the country level - between foreign and national entities from the private and public sector. Moreover, local research and development may generate technology which can be a subject of commercialisation, i.e. endogenous technology transfer.

Nevertheless, the endogenous transfer of technology is not the subject of this paper. The support for the process of transmission of a method or a product by increasing the capacity to absorb technology, e.g. by increased skills, infrastructure, or institutional mechanisms of transfer, is considered to be an indirect transfer of technology. In this paper, we concentrate on the exogenous direct and indirect, commercial and non-commercial transfers of technology and their impact on the local capacities of technology application. This is referred to as the level of technology absorption.

The contribution of this paper is as follows. First of all, the gap in the research on Sub-Saharan Africa is addressed by an attempt to measure the factors of technology absorption in the region in a quantitative way. Several papers discuss the issue, but the approach in most of them is from the country or sectoral level, usually in the microeconomic perspective (among others Mbarika et al., 2004; Bruneforth, 2010; Simiyu et al., 2010; Karani, 2002; Kruss et al., 2012; Lee et al., 2012; Yelpaala et al., 2012; Capurro, 2008; Kinuthia, 2008). In this paper, the issue is addressed as a macroeconomic problem amplified in the theories of development economics. For this reason, technology absorption was approximated with the number of articles published in "technical" journals - this approach is explained in the following subsection. With this it was possible to determine - from the perspective of statistics - which exogenous flows impact technology absorption the most. This, in turn, is important information for the policy- and decision-makers. 
The existence of long-run relationships between: technology absorption and official development aid (ODA); technology and FDI; and technology and merchandise import from developing countries was confirmed. Surprisingly, it appeared that ODA is a better technology driver than FDIs. The relation between technology absorption and FDIs is more ambiguous. However, it is the increased technology absorption that attracts FDI, and not vice versa. Support is offered to the thesis that merchandise import from developing countries may contribute to technology absorption better than merchandise import from developed countries, however the relationship is weaker than with ODA.

The paper is divided into 9 sections. The first one offers a literature overview on the selected channels of exogenous technology transfers to the region, namely development aid, foreign direct investment, and merchandise import from developed and developing countries. Next, ODA per capita is analysed along with FDI (as a percentage of GDP), merchandise import from high income economies, and merchandise import from developed economies from the outside of the region as possible explanatory variables for absorption of technology in Sub-Saharan Africa.

\section{Literature Overview}

Transfer of technology is possible with the international activity of state and non-state actors. The research by Danquah \& Ouattara (2015) suggests that trade policies on openness, machinery imports, stock of R\&D, landlockedness, and quality of institutions play a significant and quantitatively important role in explaining the differences in efficiency scores in SSA. In this paper, a different, parallel approach is adopted, namely technology transfer channels are analysed, both direct or indirect, for profit or non-profit, in terms of their contribution to the absorption of technology in the region.

Development aid is public financial flows which was defined, organised, and reported under the auspices of OECD back in the 1960s. Aid is believed to be the source of direct and indirect technology transfers (Andrzejczak \& Kliber, 2016a). Direct transfers usually take the form of projects or technical assistance (e.g. funding research, supporting dam construction), while indirect transfers increase absorption by boosting capacity (e.g. education, health, infrastructure) largely under ODA programmes (Andrzejczak \& Kliber 2015; Andrzejczak \& Kliber, 2016a). In this paper, however, no differentiation is made between the types of aid based on its form, but rather on the sector of commitment. In the previous research, the role of technology assistance was studied. It was found that the effects of technical aid are by no means more influential with respect to technology absorption than general aid (Andrzejczak \& Kliber 2016b).

The relationship between aid and technology transfers has been addressed in the literature, but so far only some aspects of it have been covered in depth. Some papers focus on agriculture research and technology, information and communications technologies in developing countries, the revolution of advanced materials, public policy and the case of biotechnology in sub-Saharan Africa, or the energy sector in Africa (Bhagavan, 1997; Cai, 2008; Baker \& Edmonds, 2004; Mbarika et al., 2004; Bruneforth, 2010, Simiyu et. al., 2010; Karani, 2002; Kruss et al., 2012; Lee et al., 2012; Yelpaala et al., 2012; Capurro, 2008; Kinuthia, 2008). The majority of research on development aid concentrates on the relation between aid and economic growth (Papanek, 1972; Easterly \& Pfutze, 2008; Radelet et al., 2006). There is still, however, some space to analyse the relation between development aid and technology. It is important to understand that while some development aid activities may enable technology transfers, other may have neutral or even negative impact on the process.

Historically, effectiveness of the aid has been heavily criticised - mainly due to the donors' attitude (Easterly \& Pfutze, 2008; Andrzejczak, 2015). The "ineffective burden" followed development aid projects, later referred to as "white elephants", which were not compatible with the recipient infrastructure, or the society (Brunel, 1993; Severino \& Charnoz, 2003). The effectiveness of technology transfers occurring via development aid channels requires establishment of long-term mechanisms facilitating knowledge, knowhow, or technology absorption. Many of the aid initiatives launched in recent decades to improve the situation have provided only short-term solutions that often eroded after the project finished because of the lack of funds for ensuring their long-term sustainability (Ovadia, 2015). The lack of sustainability reduces the 
impact of project-type interventions, even if they are successfully implemented. A project may work, but if its integration with social norms is a failure (Baker \& Edmonds, 2004), the technology in that project may be rejected in the long-term perspective.

On the other hand, high expectations are placed on programme aid funds, which are transferred to recipient economies for specific budget baskets in the selected sectors of economy (especially as the Country Programmable Aid). Enhancing country's social capability and infrastructure, especially in the area of education, can contribute to more effective external technology adaptation by creating incentives to increase production and decrease costs. According to Walley \& Cushing (2013), what is more likely to improve productivity and sustained growth in Sub-Saharan African countries is development aid aimed at stimulating activities that enhance knowledge accumulation and skills development of the workforce.

Foreign direct investments are recognised as one of the most effective ways of transferring modern technologies. They may positively affect economic growth - both as a source of financing that the receiving country's capital needs and as a driver of technology and knowledge transfer (Gulcz, 1974; Kokko, 1994; de Mello, 1997; Bezic \& Karanikic, 2014). The positive effects of FDI are enhanced if they allow for physical and human capital accumulation (Munemo, 2013; Liu et al., 2014). Multinational companies in particular are expected to bridge the gap between more and less advanced economies and to stimulate technology diffusion (Blomstrom et al., 1994). This is, however, possible only if investments integrate with the local economy. A certain level of donors' motivation to share technology and absorptive capacity in the hosting country is required to ensure actual effectiveness of the transfer (Jordaan, 2013). Thus, if a hosting country creates an environment conducive to investment, FDls can play an important role in its development and they can fill out the resource gap between domestic savings and investment requirements (Dupasquier \& Osakwe, 2005).

Nevertheless, Zeng, Wan \& Tam (2009) argue that FDIs have a dual effect on the local companies' motivation to increase the level of technology. Introduction of FDIs can force indigenous companies to move to the sections of the value chain with lower profits. Under certain conditions, FDIs may even exert negative impact on the process of technology transfer (Zeng et al. 2009). Indeed, indigenous companies must attain a certain level of absorptive capacity to decode indirect benefits from foreign presence and to benefit from FDIs (Behera, 2015). The lack of absorptive capacity decreases not only the transfer effectivity but also the FDI record (Sitek, 2000). In the case of the Sub-Saharan region, the low transfer effectiveness can be attributed to several factors: political and macroeconomic instability, low growth, weak infrastructure, poor governance, inhospitable regulatory environments, and ill-conceived investment promotion strategies (Dupasquier \& Osakwe, 2005). As a result, some contracts which should be followed with technology transfer (i.e. in the scope of FDIs) are not as profitable as they ought to be; what is more, they may even be disadvantageous as they are executed by inexperienced or dishonest agents (Kane 1998). The risk is especially high in the extraction industry (Kruss et al., 2012).

Apart from FDIs, another trade-oriented potential driver for technology in the region is imports. In the trade relations between the North and the South, imitation-based dissemination of knowledge from the technologically superior North to the less developed South proved to be crucial for technological catch-up (Datta \& Mohtadi, 2006). According to Bahmani \& Mehdi (2015) trade speeds up the transfer of technology between the regions. Permitting the import of technology enhances effectiveness of the economy (Pack \& Paxons, 1999). Especially important for the process are the imports of capital goods (Sharma \& Ambrammal, 2015). This was supported by the recent research on imports of capital goods from China. Munemo (2013) shows that they were an important channels of technology transfer which enhanced economic growth in SSA. The recognition of this and the establishment of policies which would increase these imports seems to be an import goal for the policy makers.

It is assumed in this paper that technology absorption may depend on the trade partner characteristics - the similarities between the trade partners in terms of social, cultural, and technological aspects. One can assume that imports from developed countries are more technologically advanced than imports from the emerging economies and developing countries. It is interesting to verify whether transfer 
is more feasible when the partners share some elements of technological advancements, social conduct, and institutional proximity. According to Datta \& Mohtadi (2006), a Southern country that is deficient in human capital can only imitate the goods imported from North, while Southern countries that own sufficiently large human capital endowments, beyond a certain threshold, signal the onset of innovation. For the Sub-Saharan region, this may indicate that the imports will have lesser impact on building technological capacities. One should also keep in mind that according to some researchers the relationship between technology transfer and imports is negative and significant (Ghazouani \& Teraoui, 2014). The following chapters are an attempt at finding out which of the channels, i.e., aid, FDIs, imports from developed and developing countries, are more likely to foster the absorption of technology.

\section{Approximation of Technology Transfer}

The first encountered problem was how to approximate technology transfers in African countries. One source of information was the World Economic Forum database, offering the Global Competitiveness Index. It offered an index built from survey data. One of the questions in the survey was to assess the firmlevel technology absorption on a 1 to 5 scale. However, the range of the data was relatively short - only 8 years. Therefore, another measure had to be found, which would be strongly and positively correlated with the technology data. For this reason, we analysed the technology-related data from the World Bank World Development Indicators database. We rejected high-technology exports due to the instability of data as in the case of some countries one major contract can affect the country performance. Moreover, at this point, high-technology exports are not most representative for the Sub-Saharan technology. The data on the number of patent applications was very limited and could not serve as an indicator in the regional analysis. One of other options to consider was the number of scientific and technical articles published in a given country. Scientific and technical journal articles refer to the number of scientific and engineering articles published in such fields as physics, biology, chemistry, mathematics, clinical medicine, biomedical research, engineering and technology, and earth and space sciences. With this in mind, a decision was made to study R\&D potential as an overall indicator representing the level of absorbed technology. Absorption represents here the effectiveness of technology transfer. To put it in simple terms, it was assumed that the capacity for technology generation can be the consequence of external flows, but it may also be the outcome of endogenous technology creation and national innovation.

Table 1 presents the correlation coefficients calculated for the two measures for the period 20062011 (when the data were stationary). The observed correlations were strong and positive, ranging from 0.84 for high-income non-OECD countries to 0.920 for Sub-Saharan Africa. To check the robustness of the results the rank-based Spearman's correlation coefficient was calculated as well. The obtained results were compatible with the previous conclusions.

Thus, to utilise the datasets from longer time spans, the level of technology absorption was approximated with the number of technical articles published in scientific journals. The obvious advantage was the substantial increase of the sample length- from 6 years to 26 years, as the data on the articles published in "technical" journals cover the period from 1986 to 2011. The choice of the dependent variable is somewhat similar to the application of instrumental variables in regression estimation, when the regressors are inter-correlated. The instruments were chosen in such a way that they were correlated with the original regressors but not among themselves. In our case we chose the "instrumental" dependent variable instead of the explanatory ones.

Table 1. The Correlation Between The Technology Absorption Level and The Number of Technical Articles Published in Scientific Journals for Selected Regions and Countries

\begin{tabular}{|l|l|l|l|l|}
\hline & $\begin{array}{l}\text { Lower-middle } \\
\text { income }\end{array}$ & $\begin{array}{l}\text { high income - non } \\
\text { OECD }\end{array}$ & $\begin{array}{l}\text { Latin } \\
\text { America }\end{array}$ & $\begin{array}{l}\text { Sub-Saharan } \\
\text { Africa }\end{array}$ \\
\hline Pearson's correlation & 0.945 & 0.841 & 0.845 & 0.920 \\
\hline $\begin{array}{l}\text { Spearman's } \\
\text { correlation }\end{array}$ & 0.976 & 0.833 & 0.905 & 0.976 \\
\hline
\end{tabular}




\section{The Data}

The set of potential explanatory variables consisted of variables which may exert impact on technology absorption in Sub-Saharan Africa. The following possible explanatory variables were considered:

- ODA per capita (1986-2011),

- FDI as a \% of GDP (1986-2011),

- Merchandise import from high-income economies (1986-2011),

- Merchandise import from developed economies outside the region (1986-2011),

- GDP per capita (1986-2011).

The presentation comprises the dynamics of each variable together with the dynamics of "technology" (Figures 1 to 5). First, over the course of 1986-2000 technology absorption was decreasing, while in 2000-2011 it was increasing. This may have been the consequence of the increasing economic growth rate, but also higher trade and FDIs. The change may also be explained in terms of the redefinition of aid goals in 2002, when the United Nations Millennium Project was commissioned by the United Nations Secretary-General. The purpose of the Project was to devise a plan for the world to achieve the Millennium Development Goals and to reverse the grinding poverty, hunger, and diseases affecting billions of people (see: http://www.unmillenniumproject.org/). ODA per capita and GDP per capita are similar in their dynamics to the technology absorption process. Merchandise imports from developed countries are likely to be driven by some opposite factors, while imports from developing economies seem to follow an upward trend which coincides with the upward trend in technology absorption observed from 2002.

Figure 1. ODA Per Capita vs. Technology

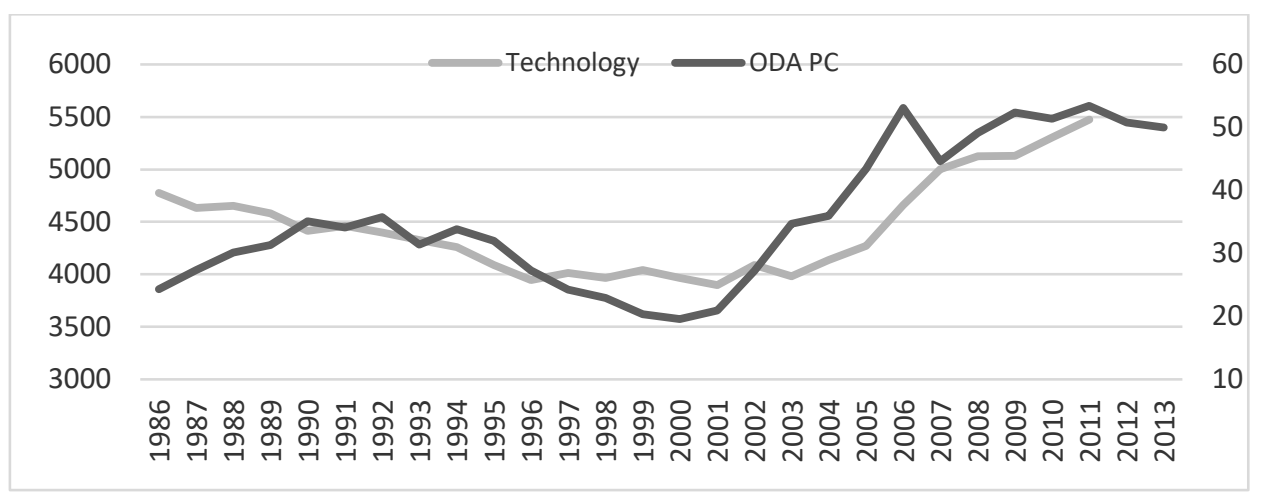

Note: ODA values - right axis, technology - left axis.

Figure 2. FDI as a Percentage of GDP vs. Technology

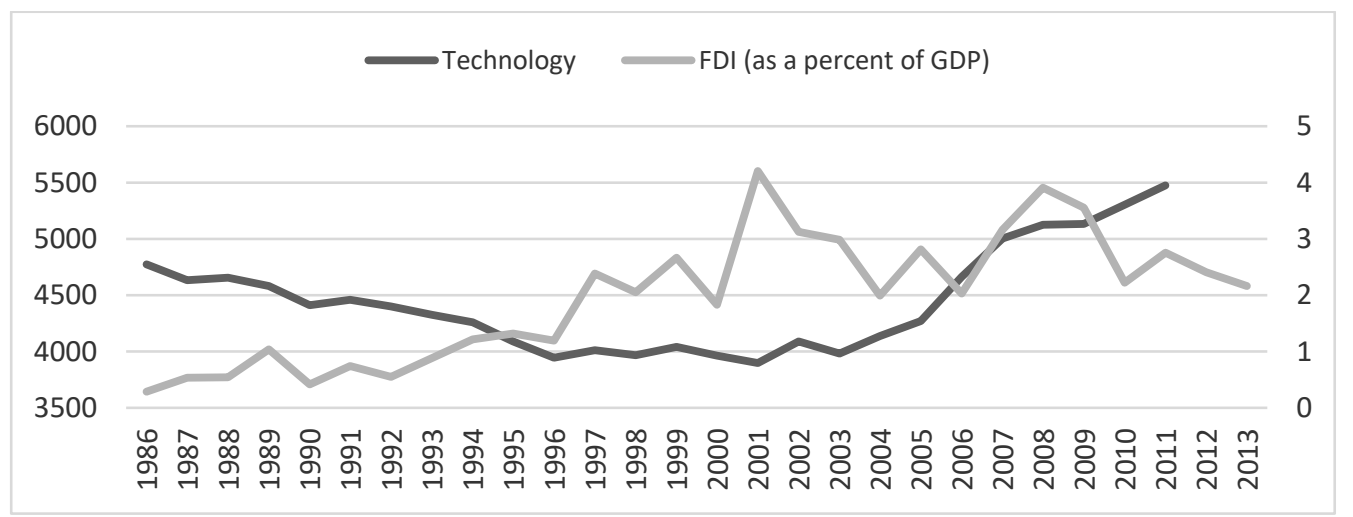

Note: FDI values - right axis, technology - left axis. 
Figure 3. Merchandise Imports from High-Income Economies vs. Technology

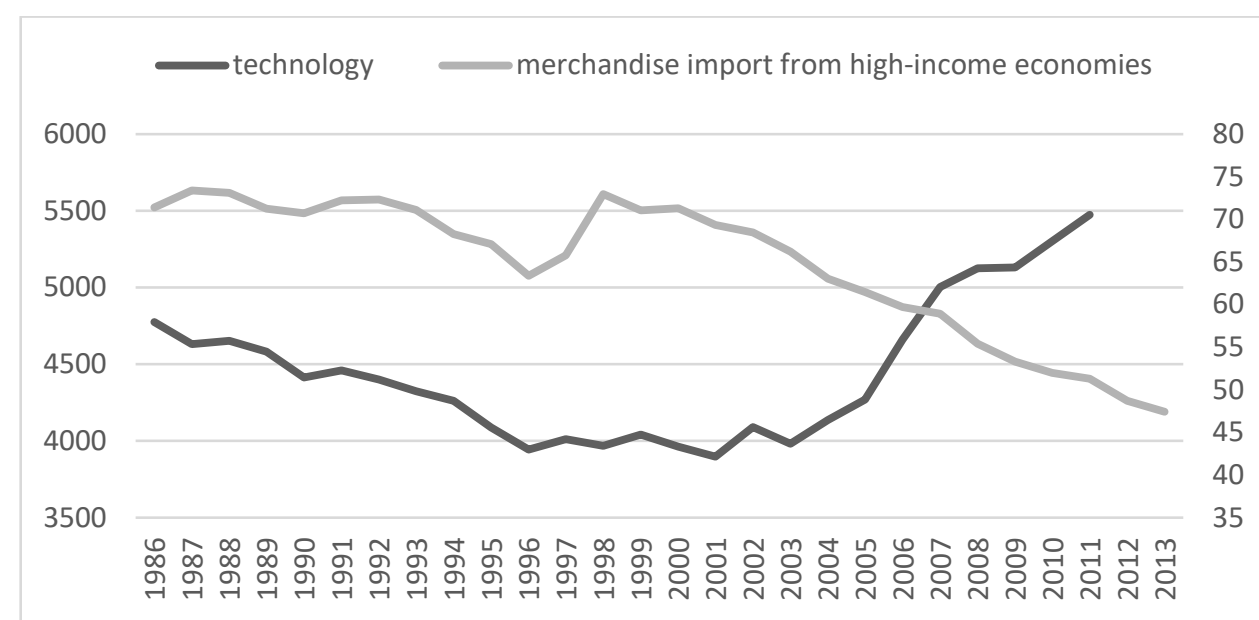

Note: import values - right axis, technology - left axis.

Figure 4. Merchandise Import from Developing Economies (Excluding Own Region) vs. Technology

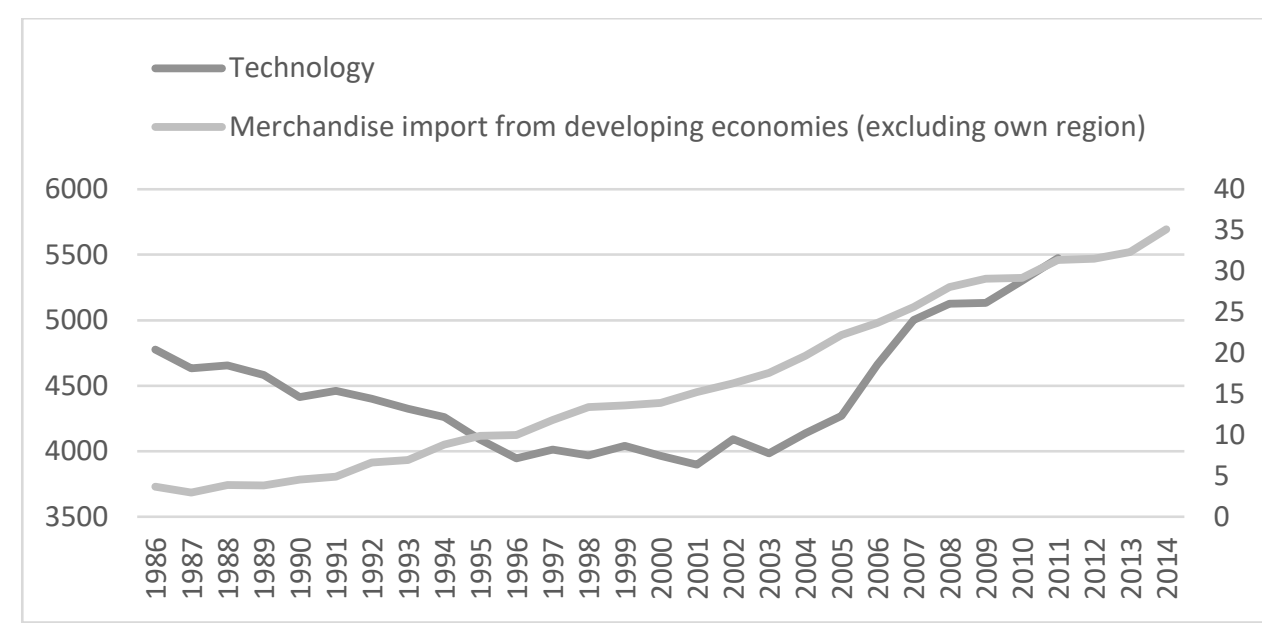

Note: import values - right axis, technology - left axis.

Figure 5.GDP Per Capita vs. Technology

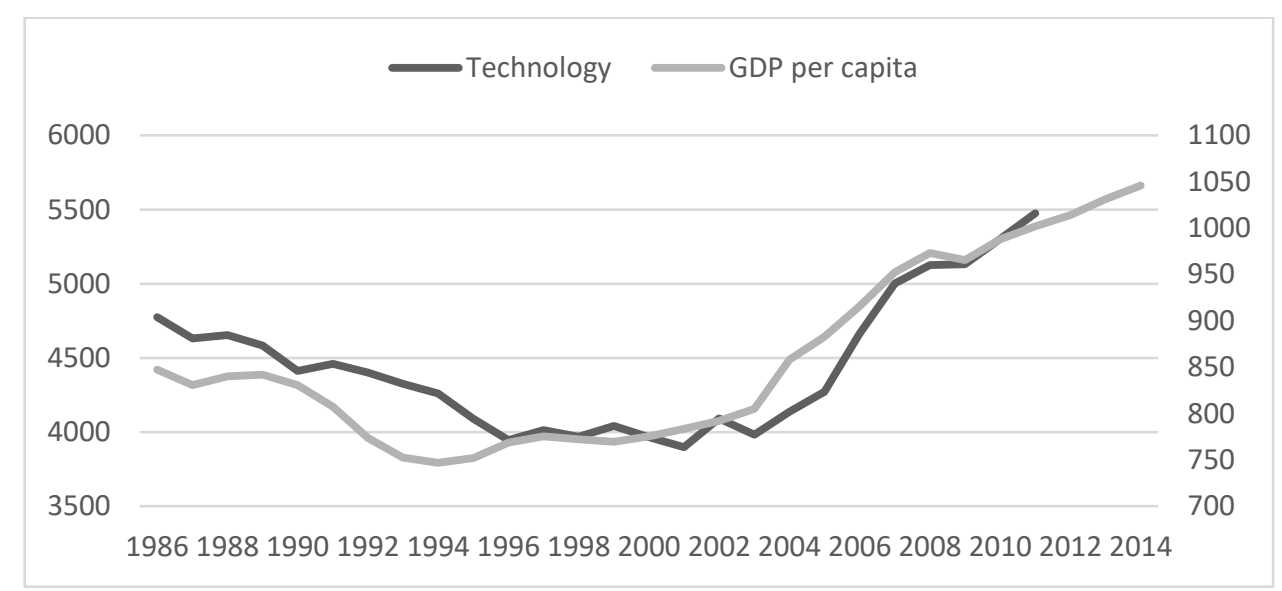

Note: GDP per capita - right axis, technology - left axis. 
The study commenced with testing the data for stationarity. As none of the variables proved to be stationary, the Johanssen (1995) procedure was applied to look for possible long-term relationships between technology transfer and each of the variables. All the computations were performed in GRETL (Cottrel \& Lucchetti, 2014).

\section{The Model}

In the research, the approach adopted was the one proposed by Gonzales and Granger (1995). Two time series $x_{t}$ and $y_{t}$ are considered, both integrated of order 1 , denoted I(1), so that their changes are stationary, i.e. I(0). The series are cointegrated if there is a linear combination $z_{t}=y_{t}-A x_{t}$, which is I(0). The relationship between the series can be presented in terms of common I(1) factor $f_{t}$, i.e.:

$$
\left[\begin{array}{l}
y_{t} \\
x_{t}
\end{array}\right]=\left[\begin{array}{l}
A \\
1
\end{array}\right] \cdot f_{t}+\left[\begin{array}{c}
\widetilde{y_{t}} \\
\widetilde{x_{t}}
\end{array}\right]
$$

where $\widetilde{y_{t}}$ and $\widetilde{x_{t}}$ are $1(0)$. Stock and Watson (1988) proved that if $\left(x_{t}, y_{t}\right)$ are cointegrated, there must exist a common representation of the form (1). The phenomenon of cointegration can be associated with the longrun equilibrium. When the long-run equilibrium is estimated, the common factor $f_{t}$ is eliminated. It is interesting, however, to retrieve the common factor and decompose $\left(x_{t}, y_{t}\right)$ into two components $\left(f_{t},\left(\tilde{x_{t}}, \tilde{y_{t}}\right)\right)$ that convey different kind of information. The common factor can be associated with the longrun relationship (permanent component), while the second component will be called transitory one. Moreover, with such decomposition it is possible to investigate how the variables are inter-related (Gonzalo and Granger, 1995).

$\mathbf{X}_{t}$ will be used to denote a $(p \times 1)$ vector of the I(1) time series. With the assumption that the rank of cointegration is $r$, there exists a matrix $\boldsymbol{\alpha}_{p \times r}$ of the rank $r$ in which $\boldsymbol{\alpha}^{\prime} \mathbf{X}_{\mathbf{t}}$ is I(0). The vector $\mathbf{X}_{t}$ has an ECM representation:

$$
\Delta \mathbf{X}_{t}=\boldsymbol{\gamma} \boldsymbol{\alpha}^{\prime} \mathbf{X}_{\mathbf{t}-\mathbf{1}}+\sum_{i=1}^{\infty} \Gamma_{i} \Delta \mathbf{X}_{t-i}+\boldsymbol{\epsilon}_{t}
$$

where $\Delta=I-L$, and $\mathrm{L}$ is the lag operator. The elements of $\mathbf{X}_{t}$ can be explained in terms of a smaller number $k=(p-r)$ of the I(1) variables, the common factors and the I(0) component:

$$
\mathbf{X}_{t}=\mathbf{A}_{1} f_{t}+\widetilde{\mathbf{X}_{t}}
$$

Gonzalo \& Granger (1995) show that the common factors can be estimated from the ECM representation (2). The authors claim that the common factors are the linear combinations of $\mathbf{X}_{t}$, i.e.

$$
\begin{aligned}
f_{t}= & \mathbf{B}_{\mathbf{1}} \mathbf{X}_{\mathbf{t}} \\
& \text { Thus - from (3) and (4): } \\
\widetilde{X_{t}=} & \left(\mathbf{I}-\mathbf{A}_{\mathbf{1}} \mathbf{B}_{\mathbf{1}}\right) \mathbf{X}_{\mathbf{t}}=\mathbf{A}_{2} \boldsymbol{\alpha}^{\prime} \mathbf{X}_{t}=\mathbf{A}_{\mathbf{2}} \mathbf{z}_{\mathbf{t}},
\end{aligned}
$$

where $z_{t}=\boldsymbol{\alpha}^{\prime} \mathbf{X}_{t}$, are the residuals from the co-integrating equation. Ultimately:

$$
f_{t}=\gamma_{\perp}^{\prime} X_{t}
$$

are the linear combinations of $\Delta X_{t}$ without the levels of the error correction term $z_{t-1}$.

Having identified the common factors, the permanent-transitory composition ( $\mathrm{P}-\mathrm{T}$ decomposition) is obtained: 


$$
X_{t}=A_{1} \gamma_{\perp}^{\prime} X_{t}+A_{2} \alpha^{\prime} X_{t}
$$

where $A_{1}=\alpha_{\perp}\left(\gamma_{\perp}^{\prime} \alpha_{\perp}\right)^{-1}$ and $A_{2}=\gamma\left(\alpha^{\prime} \gamma\right)^{-1}$. Such decomposition can be found when matrix $\alpha^{\prime} \gamma$ is not singular (Gonzalo \& Granger 1995).

\subsection{Lead-Lag Relationships in Co-Integrated System}

With the P-T decomposition one can find common factors and check which variable has a permanent or transitory effect on the system. When analysing the error-correction equation, it is advisable to check not only the significance, but also the sign of the parameter at the error-term. With the equation (2)

$$
\Delta \mathbf{X}_{t}=\boldsymbol{\gamma} \boldsymbol{\alpha}^{\prime} \mathbf{X}_{\mathbf{t}-\mathbf{1}}+\sum_{i=1}^{\infty} \Gamma_{i} \Delta \mathbf{X}_{t-i}+\boldsymbol{\epsilon}_{t}
$$

one can assume that $X_{t}=\left(y_{t}, x_{t}\right)^{\prime}$ is a 2-dimensional time-series vector made up from the technologyabsorption process and another process (e.g. ODA, FDI or import). $\Pi$ and $\Gamma_{\mathrm{i}}$ are $2 \times 2$ parameter matrices. If the two processes are non-stationary and co-integrated, then $\Pi$ is of rank 1 and the model is full VECM. In the bivariate case the co-integration model (without constant) can be written as:

$$
y_{t}=\alpha x_{t}+z_{t}
$$

and the adjustment process of the two variables $x_{t}, y_{t}$ :

$$
\begin{aligned}
& \Delta y_{t}=\gamma_{1} \hat{z}_{t-1}+\sum_{j=1}^{k} \beta_{1, j} \Delta y_{t-j}+\sum_{j=1}^{l} \delta_{2, j} \Delta x_{t-j}+\mu_{1}+u_{1, t} \\
& \Delta x_{t}=\gamma_{2} \hat{z}_{t-1}+\sum_{j=1}^{k} \beta_{2, j} \Delta y_{t-j}+\sum_{j=1}^{l} \delta_{2, j} \Delta x_{t-j}+\mu_{1}+u_{1, t},
\end{aligned}
$$

where $\gamma_{i}$ stands for the speed of adjustment of market $i$ to the long-run relationship, $\hat{z}_{t-1}$ is an estimated residual from the long-term relationship, $\beta$ and $\delta$-the coefficients to estimate. The speed of adjustment of one market to the other can be determined with the values of $\gamma_{i}$. Taking into account the relationship (8), then: $z_{t}=y_{t}-\alpha x_{t}$. If the adjustment process is to take place, then $\gamma_{1}$ must be negative, while $\gamma_{2}-$ positive. If any of the coefficients has a wrong sign or is insignificant, it is assumed that no process of adjustment takes place in the case of this variable (after: Coudert \& Gex, 2016). If both parameters have proper signs and are significant, their absolute values are compared. A higher $\lambda_{i}$ in the absolute value means that the $i$-th variable adjusts more rapidly to the other market. This implies that the $i$-th market follows the other market. A lower absolute value of $\lambda_{i}$ means that the $i$-th variable adjusts less rapidly to the other market. Thus, the process $x_{t}$ leads the process $y_{t}$ if and only if $\left|\lambda_{x}\right|<\left|\lambda_{y}\right|$ (see also e.g. Engle \& Granger, 1987, Coudert \& Gex, 2013).

\subsection{Johansen Procedure}

The Johansen (1995) procedure is used to distinguish a number of co-integrating vectors in the system. The method consists of establishing the rank of matrix $\Pi=\boldsymbol{\gamma} \boldsymbol{\alpha}^{\prime}$. Three cases can be identified:

- The rank of the matrix equals 0 - all the series are I(1) and no co-integrating relationship exists between them;

- The matrix is of full rank - all the processes are I(0) and no co-integrating relationship exists;

- The rank of the matrix is any number $r$, such as $0<r<n$ (the number of equations) - there exist $r$ co-integrating vectors. 
Usually two types of tests are provided - the trace test and the test of maximum eigenvalue. The testing procedure is step-wise. In the first step, the null hypothesis is tested in which the rank of $\Pi$ equals zero. If the null hypothesis is rejected, the test is carried out by increasing the rank by 1 , up to the moment when the null hypothesis cannot be rejected (see also e.g. Banerjee et al., 2003; Greene, 2011; Welfe, 2008).

\section{Results}

\subsection{Stationarity Tests}

Table 2 contains the results of the stationarity tests performed to check stationarity of the analysed data. The $p$-values are presented for the null hypotheses of both tests. In the case of the KPSS one (Kwiatkowski et al., 1992) under the null hypothesis states the series is stationary, while in the case of the ADF one (Dickey \& Fuller, 1979 ) - the data have a unit root. It is evident that there are some cases when the tests offered different results. For instance, when it comes to technology absorption the KPSS test gave no grounds for rejecting the hypothesis of stationarity for the model without trend, while ADF gave no grounds for rejecting the unit root hypothesis. The same was observed in the case of GDP per capita. As most of the tests carried out confirmed non-stationarity of the data, it was assumed that the series is indeed nonstationary and thus, in the next section, it will be tested for any potential long-run relationships.

Table 2. $P$-Values for the KPSS and ADF Test Statistics

\begin{tabular}{|c|c|c|c|c|}
\hline & \multicolumn{2}{|c|}{ KPSS } & \multicolumn{2}{c|}{ ADF } \\
\hline Variable: & level & trend & level & \multicolumn{2}{|c|}{0.98} \\
\hline technology & 0.09 & 0.01 & 0.99 \\
\hline ODA & 0.01 & 0.01 & 0.84 & 0.86 \\
\hline FDI & 0.01 & 0.02 & 0.39 & 0.81 \\
\hline Import from high-income economies & 0.01 & 0.01 & 0.84 & 0.93 \\
\hline Import from developing economies & 0.01 & 0.01 & 0.72 & 0.64 \\
\hline GDP PC & 0.10 & 0.01 & 0.80 & 0.85 \\
\hline
\end{tabular}

Note: Computations made in R-cran using the t-series package, and in GRETL.

\subsection{Analysis of long-run relationships}

In order to detect any long-run relationships between any of the variables and technology absorption each of the variables was tested for cointegration in the Johansen procedure (1995). The procedure confirmed the existence of long-lasting relationships between technology absorption and the remaining variables. However, both factors: the significance level and the direction of influence, differed. With respect to ODA per capita, the two tests - the trace and L-max - point to the existence of a co-integrating vector in the model with an unrestricted constant and 1 lag (see Table 3).

Table 3. Results of the Trace Test and The Maximum Eigenvalue Test for The Number of Co-Integrating Relationships Between Technology Absorption and ODA.

\begin{tabular}{|c|c|c|c|c|c|c|c|c|c|}
\hline Rank & $\begin{array}{l}\text { eigenvalu } \\
\mathrm{e}\end{array}$ & trace test & L-max test & $\begin{array}{l}\text { eigenvalu } \\
\text { e }\end{array}$ & trace test & L-max test & $\begin{array}{l}\text { eigenvalu } \\
\mathrm{e}\end{array}$ & trace test & L-max test \\
\hline \multicolumn{4}{|c|}{ Model without constant } & \multicolumn{3}{|c|}{ Model with unrestricted constant } & \multicolumn{3}{|c|}{ Model with restricted constant } \\
\hline $\mathrm{HO}: \mathrm{r}=0$ & 0.43 & \begin{tabular}{|l|}
16.09 \\
$(0.01)$ \\
\end{tabular} & $\begin{array}{l}13.83 \\
(0.02) \\
\end{array}$ & 0.49 & $\begin{array}{l}16.87 \\
(0.03)\end{array}$ & $\begin{array}{l}16.75 \\
(0.02)\end{array}$ & 0.49 & $\begin{array}{l}19.32 \\
(0.07) \\
\end{array}$ & $\begin{array}{l}16.965 \\
(0.03) \\
\end{array}$ \\
\hline $\mathrm{HO}: \mathrm{r}=1$ & 0.09 & $\begin{array}{c}2.26 \\
(0.16)\end{array}$ & $\begin{array}{c}2.26 \\
(0.16)\end{array}$ & 0.01 & $\begin{array}{c}0.12 \\
(0.72)\end{array}$ & $\begin{array}{c}0.12 \\
(0.724)\end{array}$ & 0.09 & $2.36(0.71)$ & $2.36(0.71)$ \\
\hline $\begin{array}{l}\text { Log- } \\
\text { likelihoo } \\
\text { d }\end{array}$ & -153.593 & & & -151.977 & & & \multicolumn{3}{|l|}{-151.977} \\
\hline
\end{tabular}

Note: Computations made using GRETL. 
The Johansen (1995) test suggests that a long-run relationship exists between the variables, which takes the following form (model with an unrestricted constant):

TECH $H_{t}=66.969 \cdot O D A_{t}$

Therefore, it was concluded that in the long run the increase in ODA entails an increase in the technology absorption level. The results of the VECM equation estimation can be found in Table 4 . In the equation for ODA all the variables were insignificant, while in the equation for technology - all were significant.

Table 4. Parameters of the Error Correction Equation of Technology Absorption and ODA

\begin{tabular}{|c|l|l|l|}
\hline & \multicolumn{3}{|c|}{ Right-hand variable } \\
\hline Left-hand variable & constant & \multicolumn{1}{|c|}{$\left(T E C H_{t-1}-O D A_{t-1}\right)$} & $\mathrm{R}^{2}$ \\
\hline$\Delta T E C H_{t}$ & $487.277(0.001)$ & $-0.214(0.004)$ & 0.432 \\
\hline$\triangle O D A_{t}$ & $-1.732(0.675)$ & $0.002(0.474)$ & 0.022 \\
\hline
\end{tabular}

Note: computations made using GRETL.

The residuals from the ECM equation were tested for stationarity and autocorrelation. The KPSS test confirmed stationarity of the data, and autocorrelation was not found in $\epsilon_{t} \cdot \mathrm{R}^{2}$ for the equation which amounted to 0.43 (while the adjusted one to 0.41 ). Next, one ought to concentrate on the error-correction parameter in the equation for technology. The value of the parameter amounted to -0.214 (with $p$-value $<0.001$ ); this may mean that $21.4 \%$ of the deviation from the long-run relationship between technology absorption and ODA is corrected after a year. Moreover, since the error-correction term in the second equation proved to be insignificant, $\gamma^{\prime}=(1,0)$ and $\gamma_{\perp}^{\prime}=(0,1)$.

The (P-T) decomposition of the system can be written down in the following way:

$\left[\begin{array}{c}T E C H_{t} \\ O D A_{t}\end{array}\right]=\left[\begin{array}{l}1 \\ 1\end{array}\right] \cdot f_{t}+\left[\begin{array}{l}1 \\ 0\end{array}\right] \cdot z_{t}$,

where:

$z_{t}=\alpha^{\prime}\left(T E C H_{t}, O D A_{t}\right)^{\prime}=T E C H_{t}-O D A_{t}$

and

$f_{t}=\gamma_{\perp}^{\prime}\left(T E C H_{t}, O D A_{t}\right)=O D A_{t}$.

Hence, the common factor in the case in question is:

$f_{t}=(0,1) \cdot\left[\begin{array}{c}T E C H_{t} \\ O D A_{t}\end{array}\right]$,

a multiple of the ODA variable. This means that if ODA is kept constant, any change in technology absorption is going to affect the $\left[\begin{array}{c}T E C H_{t} \\ O D A_{t}\end{array}\right]$ only through $z_{t}$, i.e. the transitory component. Therefore, it will have only transitory effect on the system.

In other words: any shock (change) of ODA has a permanent (long-run) effect on ODA and technology, while any shock in technology absorption with no movement in ODA is fully transitory. The reaction of technology absorption triggered by the shock in ODA is partially transitory and partially permanent. However, if ODA is kept constant, the response of technology absorption to the shock in technology is almost entirely transitory.

In the case of the relationships between technology absorption and FDI, both - the trace test and the maximum eigenvalue test, support the hypothesis of one co-integrating vector for the technology and FDI system, however on the 0.06 significance level (the equation without the constant and with 1 lag) - see Table 5. 
Foreign Technology Absorption in Sub-Saharan Africa: A Long-Term Analysis of the Nature and Stability of Relationships

Table 5. Results of the Trace Test and The Maximum Eigenvalue Test for The Number Of Co-Integrating Relationships Between Technology Absorption and FDI.

\begin{tabular}{|c|c|c|c|c|c|c|c|c|c|}
\hline Rank & $\begin{array}{l}\text { Eigen } \\
\text { Value }\end{array}$ & Trace Test & L-Max Test & $\begin{array}{l}\text { Eigen } \\
\text { Value }\end{array}$ & Trace Test & L-Max Test & $\begin{array}{l}\text { Eigen } \\
\text { Value }\end{array}$ & $\begin{array}{c}\text { Trace } \\
\text { Test }\end{array}$ & $\begin{array}{c}\text { L-Max } \\
\text { Test }\end{array}$ \\
\hline \multicolumn{4}{|c|}{ Model without constant } & \multicolumn{3}{|c|}{ Model with unrestricted constant } & \multicolumn{3}{|c|}{ Model with restricted constant } \\
\hline $\mathrm{HO}: r=0$ & 0.35 & $\begin{array}{l}11.92 \\
(0.06)\end{array}$ & $\begin{array}{l}10.71 \\
(0.06)\end{array}$ & 13.67 & $16.87(0.32)$ & $\begin{array}{l}12.46 \\
(0.17) \\
\end{array}$ & 0.39 & $\begin{array}{l}12.38 \\
(0.14) \\
\end{array}$ & $\begin{array}{l}12.32 \\
(0.1)\end{array}$ \\
\hline HO: $r=1$ & 0.05 & $\begin{array}{c}1.21 \\
(0.32)\end{array}$ & $\begin{array}{c}1.21 \\
(0.32)\end{array}$ & 0.01 & $\begin{array}{c}1.21 \\
(0.91)\end{array}$ & $\begin{array}{c}1.21 \\
(0.91)\end{array}$ & 0.002 & $\begin{array}{c}0.06 \\
(0.81)\end{array}$ & $\begin{array}{c}0.06 \\
(0.81)\end{array}$ \\
\hline $\begin{array}{l}\text { Log- } \\
\text { likelihood }\end{array}$ & \multicolumn{3}{|l|}{-114.656} & \multicolumn{3}{|l|}{-113.78} & \multicolumn{3}{|l|}{-113.78} \\
\hline
\end{tabular}

Note: Computations made using GRETL.

Therefore, it is the weakest supported relationship of all the presented ones. The relationship takes following the form:

TECH $H_{t}=2501.6 \cdot F D I_{t}$

FDI here is expressed as a percentage of GDP, however no support was found for the hypothesis about the long-run relationship between technology and GDP - neither expressed in a per-capita variable nor in real terms. In this case all the explanatory variables proved to be significant in both equations. The residuals from the equations were tested for stationarity and autocorrelation. Since the residuals from the second equation exhibit autocorrelation, lagged changes of technology absorption and FDI were added to the equations. The variables did not prove to be significant in the second equation, but the residuals obtained from it did not exhibit any autocorrelation. Moreover, adding the explanatory variables to the first equation contributed to the growth of $R^{2}$ from 0.23 to 0.41 (while the adjusted $R^{2}$ changed from 0.23 to 0.36 ). The resulting estimates of the equation are presented in Table 6.

Table 6. Parameters of the Error Correction Equation of Technology Absorption and FDI

\begin{tabular}{|c|l|l|l|l|l|}
\hline & \multicolumn{5}{|c|}{ Right-hand variable } \\
\hline $\begin{array}{l}\text { Left-hand } \\
\text { variable }\end{array}$ & Constant & $\left(T E C H_{t-1}-F D I_{t-1}\right)$ & $\Delta T E C H_{t-1}$ & $\Delta F D I_{t-2}$ & $\mathrm{R} 2$ \\
\hline$\Delta T E C H_{t}$ & 0 & $-0.018(0.083)$ & $0.393(0.052)$ & $\begin{array}{l}-57.623 \\
(0.099)\end{array}$ & 0.41 \\
\hline$\Delta F D I_{t}$ & 0 & $0.0001(0.025)$ & $0.002(0.164)$ & $0.259(0.215)$ & 0.29 \\
\hline
\end{tabular}

Note: Computations performed using GRETL.

The error-correction term in the $\triangle T E C H_{t}$ equation amounted to -0.018 ; this may mean that $18 \%$ of the long-run equilibrium deviation is corrected after a year. In the second error-correction equation (for $\triangle F D I)$ all the variables, except for the error-correction term, proved to be insignificant. The error correction term in the new equation amounted to 0.0001 (with $p$-value of 0.024 ), whereas in the first version of the equation it was insignificant. This may mean that $0.01 \%$ of the deviation of the FDI from the long-run equilibrium is corrected after a year. Since the absolute value of the parameter $\nu_{1}$ is higher than the absolute value of the parameter $\gamma_{2}$, we can say that the FDI inflow leads to the technology absorption process.

On the other hand, the $p$-value of the error-correction term in the technology equation is 0.08 , i.e. more than the usually accepted probability. This would mean that $\gamma^{\prime}=(0,1)$ and $\gamma_{\perp}^{\prime}=(1,0)$, which is in contradiction to the previously discussed cases. Hence, the common factor in the case in question would be: $f_{t}=(1,0) \cdot\left[\begin{array}{c}T E C H_{t} \\ F D I_{t}\end{array}\right]$, a multiple of the TECH variable. This means that if technology absorption is kept fixed, any change in $\mathrm{FDI}$ is going to affect the $\left[\begin{array}{c}T E C H_{t} \\ F D I_{t}\end{array}\right]$ only through $z_{t}$, i.e. the transitory component. Therefore, it will have only transitory, not the long-run, effect on the system. 
In the case of merchandise imports the hypothesis of long-run relationships was validated only for the imports from developing countries located outside the region (see Table 7). The relationship was found in the case of the model with an unrestricted constant.

Table 7. Results of the Trace Test and The Maximum Eigenvalue Test for The Number of Co-Integrating Relationships Between Technology Absorption and Import From Developing Countries

\begin{tabular}{|c|c|c|c|c|c|c|c|c|c|}
\hline Rank & $\begin{array}{l}\text { Eigen } \\
\text { Value }\end{array}$ & Trace Test & L-Max Test & $\begin{array}{l}\text { Eigen } \\
\text { Value }\end{array}$ & $\begin{array}{c}\text { Trace } \\
\text { Test }\end{array}$ & $\begin{array}{c}\text { L-Max } \\
\text { Test }\end{array}$ & $\begin{array}{l}\text { Eigen } \\
\text { Value }\end{array}$ & Trace Test & L-Max Test \\
\hline \multicolumn{4}{|c|}{ Model without constant } & \multicolumn{3}{|c|}{ Model with unrestricted constant } & \multicolumn{3}{|c|}{ Model with restricted constant } \\
\hline $\mathrm{HO}: r=0$ & 0.70 & $\begin{array}{c}41.29 \\
(<0.01)\end{array}$ & $29.76(<0.01)$ & 0.49 & $\begin{array}{l}17.28 \\
(0.02) \\
\end{array}$ & $\begin{array}{l}16.66 \\
(0.02) \\
\end{array}$ & 0.72 & $43.73(<0.01)$ & $32.08(<0.01)$ \\
\hline $\mathrm{HO}: \mathrm{r}=1$ & 0.37 & $11.53(<0.01)$ & $\begin{array}{c}11.53 \\
(<0.01)\end{array}$ & 0.002 & $\begin{array}{c}0.63 \\
(0.43)\end{array}$ & $0.63(0.43)$ & 0.37 & $\begin{array}{l}11.66 \\
(0.02)\end{array}$ & $11.66(0.02)$ \\
\hline $\begin{array}{l}\text { Log- } \\
\text { likelihood }\end{array}$ & \multicolumn{3}{|l|}{-110.952} & \multicolumn{3}{|l|}{-109.729} & \multicolumn{3}{|l|}{-109.729} \\
\hline
\end{tabular}

Note: Computations made using GRETL.

The relationship takes the following form:

TECH $_{t}=194.01 \cdot I M P_{t}+z_{t}$.

As in the previous cases, the short-term adjustments to the long-run relationships were modelled as well (Table 8).

TABLE 8. Parameters of the Error Correction Equation of Technology Absorption and Import

\begin{tabular}{|c|l|l|l|}
\hline & \multicolumn{3}{|c|}{ Right-hand variable } \\
\hline Left-hand variable & constant & $\left(T E C H_{t-1}-194.01 \cdot I M P_{t-1}\right)$ & $\mathrm{R} 2$ \\
\hline$\Delta T E C H_{t}$ & $140.728(0.001)$ & $-0.065(0.004)$ & 0.45 \\
\hline$\Delta I M P_{t}$ & $1.570(<0.001)$ & $-0.0002(0.015)$ & 0.23 \\
\hline
\end{tabular}

Note: Computations made using GRETL.

The residuals from the ECM equation were tested for stationarity and autocorrelation. The KPSS test confirmed stationarity of the data, while autocorrelation was not found in $\epsilon_{t} \cdot \mathrm{R}^{2}$ for the equation which amounted to 0.45 (while the adjusted one to 0.42 ). Next, focus is given to the parameter $\gamma 1$ in the error correction term in the equation for technology. The value of the parameter amounted to -0.065 (with $p$ value: 0.001 ); this may mean that $6.5 \%$ of the deviation from the long-run relationship between technology absorption and import is corrected after a year. On the other hand, the coefficient $\gamma_{2}$ in the short-run adjustment equation for imports has a negative sign as well, which means that the process of import does not adjust to the long-run relationship. Again - the response of technology triggered by an import shock is partially permanent and partially transitory; with imports kept constant, the response of technology to a technology shock is only transitory.

Surprisingly, no long-run relationships were found between GDP (neither in current nor in constant prices) or technology absorption for any of the models (without any constant, with a restricted constant, and an unrestricted constant). For the sake of consistency, the results of the tests are not presented in this paper.

\section{Conclusions}

The absorption of technology during 1986-2000 was visibly declining, while in 2000-2011 it was growing. On the one hand, this may indicate that the redefinition of development aid policies, being the consequence of the hard situation in the African states in the late 20th century, was effective. On the other, this may stem from the general tendency of the economic growth boosting in the region and the improved situation in the last decade affected by the higher level of political stability in the region, increased inflows of capital goods from the Global South (including China, India and Brazil). 
If we look at ODA, FDI, and imports from the theoretical perspective, all of them constitute the potential sources of technology absorption in the recipient country. If managed properly, they can include transfer of cognitive structures and know-how in the form of projects or programmes, and their integration with the hosting economy. However, the results of the research presented herein reveal a different tendency when it comes to their effects in the Sub-Saharan region over the period in question. Absorption of technology is all about a change of social institutions and order, which requires a cultural change of practice. Several factors can disrupt the process of technology transfer. For this reason, technology offered through aid may be more easily absorbed.

In the long run the increase in ODA entails an increase in the technology absorption level; while thesis that FDIs promote technology absorption in Sub-Saharan Africa found no validation herein. The authors argue that technology absorption requires a certain level of readiness on the recipient's part. The flows of aid to social services, production sectors as well as infrastructure enable a direct and indirect technology transfer by building the capacity of the local environment to absorb it and introduce technology. A large part of aid transfer is directed to education, which can also explain the relation between the improvement in human capital quality and technology absorption. Therefore, development aid may increase the absorptive capacity and introduce technology at the same time.

The impact of aid on technology absorption may be greater since the extent of aid is greater that FDIs in the large part of the period under analysis. Only lately has the value of FDIs (in absolute terms) surpassed the level of ODA provided to the region. The value of FDIs grew only after 2005 (it reached over USD 30 billion in 2007); in the period of 2000-2015 it increased fivefold. At the same time, it should be noted that the list of the major recipients of FDIs is short and FDIs calculated for the entire group find their way to the very few of its members (e.g. Nigeria, South Africa, Ghana, Mozambique, Zambia). This means that FDIs do not contribute equally to the general regional technology transfer and growth. Moreover, until recently, the majority of FDls in Africa were directed to the primary sector, especially oil and petrol. Such FDIs do not contribute to other sectors' growth and are less susceptible to spillovers. Typically, such investments become technology islands which are isolated from the economy. Moreover, especially in the Sub-Saharan Africa, FDls do not generate enough employment.

The transfers of technology to host markets and the resultant spillover effects are considered to be a natural outcome of exogenous technology which involves intervention. However, the significance of the technology gap size, technological advancement in the investment sector, structure and development of the market, quality of human capital along with other factors play a major role in actual technology absorption. When it comes to the Sub-Saharan region, it was found that the nature of the FDI flows as well as the conditions of recipients' economies may diminish the potential influence of FDIs on technology absorption.

In turn, upon acceptance of the high $p$-value, FDI indeed precedes the technology absorption process. The interviews conducted in 2015 and 2016 with Polish entrepreneurs who wished to expand the SubSaharan market indicate that investors prefer technologically-advanced countries for their investments. On the other hand, to be able to move the long-run relationship between FDI and ODA, ODA itself or ODA and FDI together need to be modify. If ODA is kept fixed while FDI is changed, we can only modify the short-term deviations from the trend. The long-run FDI-technology relationship can be modified by investments in technology, not the other way around. In further research it would be interesting to find out which sectors and origin of investors react to the increase of technology.

It was found that any shock (change) of ODA exerts a permanent (long-run) effect on technology absorption, while the technology absorption response to an import shock is partially permanent and partially transitory. This indicates that the impact of incoming aid flows is crucial, and that policymakers should consider the stability of their disbursements aimed to increase technological capabilities in recipient countries. This may be explained through the implementation of aid programmes, which - unlike imports usually have a long-term strategy of creating impact. On the other hand, the delayed response of the longrun relationship between technology absorption and import may result from the fact that the process requires time to complete the distribution of goods and the dissemination of know-how therein. 
The structural adjustment policies, which enhanced trade openness, failed to lift the region in question out of poverty. Moreover, the perception of experiences with the Washington Consensus in the region is rather negative; the suggested economic doctrines are believed to be the source of unfavourable processes in the respective economies, which only strengthened pre-industrial structures within such economies. The neo-colonial practices, understood as the overall policy of the former metropolis to maintain economic influence in their historic colonies, bring back negative memories and lack any positive economic outcome, or a sound policy message. Nevertheless, it is mostly openness of the economy and foreign influence that may bring the knowledge, and hence the technology, to a single country, and to the entire region, as the Central-Eastern European experience shows. Also, despite the criticism of development aid, apparently the non-commercial flows have the capacity to exert an impact for stimulating technology absorption and readiness. Finding ways to a more effective transfer of technology (especially in the sphere of agriculture) in Sub-Saharan Africa is a crucial task for the years to come. Increased technological capacity of agriculture may be vital to structural transformation and to increasing the quality of life in the region.

\section{End Notes}

1. In this paper, we concentrate on the development aid understood as the Official Development Assistance within the meaning provided by and registered in the OECDstat database. We are aware that the perception of the development cooperation system keeps evolving and that a number of unreported flows exist (e.g. China), however we resolved to take into account only ODA due to the availability of data.

\section{References}

Andrzejczak, K. (2015). The Sources of technology development in Sub-Saharan Africa. Science to Business (S2B): Research and Innovations, 2, 5-28.

Andrzejczak, K., \& Kliber, A. (2015). The model of French development assistance - who gets the help? Dynamic Econometric Models, 15(2015), 89-109. DOI http://dx.doi.org/10.12775/DEM.2015.005

Andrzejczak, K., \& Kliber, A. (2016a). Development cooperation models with African countries. Models based on donor approach and recipient structure. In: C. Talesco, F. Sai, K. Ng, D. Ip (eds.), Development: What Now? Past, Present and Future Challenges in International Development, Hong Kong: the Hong Kong Polytechnic University Press, 292-321.

Andrzejczak, K., \& Kliber, A. (2016b). FDI or ODA, which one is a better technology absorption driver for Sub-Saharan Africa?, Working Paper presented at the Conference on Applications of Mathematics and Informatics in Economics, April 15-16th, 2016, Poznan, Poland

Bahmani, M., \& Mehdi, N. (2015). Trade-based technology transfer and its impact on the Iranian economy: Using a CGE model. Iranian Economic Review, 19(1), 107-122

Banerjee, A., Dolado, J., Galbraith, J.W., \& Hendry, D.F. (2003) Co-integration, error correction, and the econometric analysis of non-stationary data. New York: Oxford University Press.

Blomstrom, M., Kokko, A., \& Zejan, M. (1994). Host country competition and technology transfer by multinationals. Weltwirtschaftliches Archiv, 130(3), 521 - 533.

Bruneforth, M. (2010). Higher education in sub-Saharan Africa - A statistical portrait. UIS Workshop on education statistics, Windhoek, (October, 2010), 17-21.

Brunel, S. (1993). Le gaspillage de l'aide publique. Paris: Editions du Seuil, Paris.

Capurro, R. (2008). Information ethics for and from Africa. Journal of the American Society for Information Science \& Technology, 59(7), 1162-1170.

Comin, D. A., \& Mestieri F. M. (2013). Technology diffusion: Measurement, causes and consequences. NBER Working Paper (w19052).

Cottrel, A., \& Lucchetti, R.J. (2014). Gretl user's guide, GNU Regression, Econometrics and Time-series Library. WebDOC: http://gretl.sourceforge.net/gretl-help/gretl-guide.pdf 
Foreign Technology Absorption in Sub-Saharan Africa: A Long-Term Analysis of the Nature and Stability of Relationships

Coudert, V., \& Gex, M. (2013). The interactions between the credit default swap and the bond markets in financial turmoils. Review of International Economics, 21(3), 492 - 505.

Datta, A., \& Mohtadi, H. (2006). Endogenous imitation and technology absorbtion in a model of North-South trade. International Economic Journal, 20(4), 431-459.

Dickey, D.A., \& Fuller, W.A. (1979). Distribution of the estimators for autoregressive time series with a unit root. Journal of the American Statistical Association, 74, 427-431.

Easterly, W., \& Pfutze, T. (2008). Where does the money go? Best and worst practices in foreign aid. Journal of Economic Perspectives, 22(2), $29-52$.

Engle, R. F., \& Granger, C. W. J. (1987). Co-integration and error correction: Representation, estimation, and testing. Econometrica, 55, 251-276

Farahmand, S., Sameti, M., \& Sasan, S. S. (2014). Spatial variations of beta-convergence coefficient in Asia: The GWR approach. Iranian Economic Review, 18(1), 81-101.

Ghazouani, A., \& Teraoui, H. (2014). Technology transfer and FDI: Some lessons for Tunisia. Asian Economic and Financial Review, 4(1), 90-104.

Gonzalo, J., \& Granger, C.(1995). Estimation of common long-memory components in cointegrated system. Journal of Business and Economic Statistics, 13(1), $27-35$.

Greene, W.H. (2011). Econometric analysis. 7th edition, Pearson.

Gulcz, M. (1974). Zdolność krajów gospodarczo nierozwiniętych do wchłonięcia i zwrotu zagranicznej pomocy inwestycyjnej, Poznan: Adam Mickiewicz University Press.

Johansen, S. (1995). Likelihood-based inference in cointegrated vector autoregressive models. Oxford: Oxford University Press.

Kaplan, D.E. (1999). On the literature of the economics of technological change. South African Journal of Economics, 67, 255-262. doi:10.1111/j.1813-6982.1999.tb01155.x

Karani, P. (2002). Technology transfer to Africa: Constraints for CDM operations. Refocus, 3(3), 20 - 23.

Kinuthia, W. (2008). Another spotlight on the continent: TechTrends in Africa. Techtrends, 52(4), 21 - 23.

Kruss, G., Adeoti, J., \& Nabudere, D. (2012). Universities and knowledge-based development in Sub-Saharan Africa: Comparing university-firm interaction in Nigeria, Uganda and South Africa. Journal of Development Studies, 48(4), 516-530.

Kwiatkowski, D., Phillips, P. C. B., Schmidt, P., \& Shin, Y. (1992). Testing the null of stationarity against the alternative of a unit root: How sure are we that economic time series have a unit root? Journal of Econometrics, 54, 159-178.

Lee, S. H., Levendis, J., \& Gutierrez, L. (2012). Telecommunications and economic growth: An empirical analysis of SubSaharan Africa. Applied Economics, 44(4-6), 461-469.

Lin, J. Y., Sun, X., \& Jiang, Y. (2013). Endowment, industrial structure, and appropriate financial structure: A new structural economics perspective. Journal of Economic Policy Reform, 16(2), 109-122.

Lin, J. Y. (2011). New structural economics: A framework for rethinking development. World Bank Research Observer, 26(2), 193-221.

Mbarika V., Kah, M.M.O., \& Keita, M. (2004). The diffusion of cyber cafés in Sub-Saharan Africa: Country case studies, innovations through information technology. Proceedings of the IRMA International Conference, 964-967.

Mcmillan, M., Rodrik, D., \& Verduzco-Gallo, Í. (2014). Globalization, structural change, and productivity growth, with an update on Africa. World Development, 63, 11-32.

Oluwatobi, S., Efobi, U., Olurinola, I., \& Alege, P. (2015). Innovation in Africa: Why institutions matter. South African Journal of Economics, 83, 390-410. doi:10.1111/saje.12071

Ovadia, D. C. (2015). Improving access to Africa's geological information through the 'billion dollar map' project. Mineral Economics, 28(3), 117-121. doi:http://dx.doi.org.ebsco.han3.ue.poznan.pl/10.1007/s13563-015-0074-z

Pack, H., \& Paxson, C. (1999). Is African manufacturing skill-constrained? World Bank Policy Research Working Papers, http://dx.doi.org/10.1596/1813-9450-2212

Papanek, G.F. (1972). The effect of aid and other resource transfer on savings and growth in less developed economies. The Economic Journal, 82(327), 934-50.

Radelet, S., Clemens, M., \& Bhavnani, R. (2006). Aid and growth: The current debate and some new evidence. In: P. Isard, L. Lipschitz, A. Mourmouras \& B. Yontcheva (eds.) The Macroeconomic Management of Foreign Aid: Opportunities and Pitfalls, 43-60. Washington, DC: International Monetary Fund. 
Severino, J.M., \& Charnoz, O. (2003) Un paradoxe du développement? Revue d’Economie du Développement, 17(4), 77 $-97$.

Sharma, R., \& Ambrammal, S. K. (2015). International technology transfer and domestic patent policy: An empirical analysis of Indian industry. Journal of Developing Areas, 49(3), 165-181.

Simiyu, K., Masum, H., Chakma, J., \& Singer, P. A. (2010). Turning science into health solutions: KEMRI's challenges as Kenya's health product pathfinder. BMC International Health \& Human Rights, 10 (Suppl. 1), 1-9. doi:10.1186/1472-698X-10-S1-S10.

Solow, R.M. (1956). A contribution to the theory of economic growth, Quarterly Journal of Economics, LXX, 65-94.

Stock, J., \& Watson, M. (1988). Testing for common trends, Journal of the American Statistical Association, 83, 10971107

Walley, B., \& Cushing, M. (2013). Development aid and foreign R\&D spillovers in Sub-Saharan Africa. International Journal of Applied Economics, 10(2), 10-31.

Welfe, A. (2008) Ekonometria. Metody i ich zastosowania (in Polish), Polskie Wydawnictwo Ekonomiczne, Warszawa.

Yelpaala, K., Elron, B., Awase E.B., Vänskä R., Parker J.P., Joshua T.B., Adepoju, S., Agamah, A., \& Bello, I. (2012). The big question: Upwardly mobile: What role should technology play in Africa's development? World Policy Journal, 29(4), 3-7. 
This Page Intentionally Left Blank 